\title{
Microbial Processes and Natural Gas Accumulations
}

\author{
Barry Jay Katz
}

\author{
Chevron Energy Technology Company, 1500 Louisiana Street, Houston, TX 77002, USA
}

\begin{abstract}
Microbial processes are responsible for the formation, alteration, and destruction of some natural gas accumulations. Individual microbial gas accumulations may be significant ( $>1$ Tcf; trillion cubic feet or 28.3 billion cubic meters) and collectively account for more than $20 \%$ of the global gas resource-base, dominating in some individual basins. Often cited resource estimates do not effectively account for the contribution of microbial gas to mixed biogenicthermogenic gases nor do these estimates fully account for secondary microbial gas.

Microbial gas accumulations form through multiple stages, initiating with the breakdown of large macromolecules into smaller components that the methanogens can effectively utilize as an energy source. There are two primary methanogenic pathways, acetate fermentation and $\mathrm{CO}_{2}$ reduction, both of which may utilize sedimentary organic matter or preexisting oil accumulations as a source.

Microbial gas is typically considered dry (i.e., depleted in $\mathrm{C}_{2+}$ components), but there is clear evidence that ethane and possibly propane may also form through microbial processes.

Numerous authors have provided guidance on the conditions that favor primary microbial gas formation and accumulation including: an anoxic setting, high rates of sedimentation, formation of early traps, low temperatures, favorable migration history, and limited availability of sulfate. Scenarios conducive with secondary microbial gas accumulations have also been discussed. These include the presence of a significant oil pool that can be biodegraded or a coal or organic-rich shale that has achieved thermal maturity levels approaching or beyond the top of the oil-window, which have been uplifted, fractured, and invaded by meteoric water to reintroduce a microbial population.

Gas accumulations may also be biodegraded. Biodegradation results in the preferential removal of $\mathrm{C}_{3-5} n$-alkanes, leaving isotopically heavier residuals. Ethane is relatively resistant to biodegradation compared to the $\mathrm{C}_{3+}$ homologues. At more advanced levels of biodegradation, the wet gas components are removed yielding a dry gas. As with the biodegradation of oil, the biodegradation of a gas accumulation results in a reduction of the resource-base. The molecular and isotopic compositional changes induced by bacterial alteration of gas accumulations can often complicate their interpretation suggesting more advanced levels of thermal maturity.
\end{abstract}

Keywords: Acetate fermentation, Biodegradation, Carbon isotopes, $\mathrm{CO}_{2}$ reduction, Methanogenesis, Microbial gas.

\section{INTRODUCTION}

Historically natural gas has not been a focus of hydrocarbon exploration and was often a byproduct of oil exploration. Unlike oil, natural gas suffered a limited transportation infrastructure and somewhat limited demand. Natural gas discovered in remote locations as part of an oil exploration program was often termed "stranded" and could go undeveloped for decades. For example, Gorgon Field, Australia, was discovered in 1981 with the final investment decision to go-forward with development made in 2009. If produced, associated gas would commonly be flared, such as in the Niger Delta, where estimates of gas flaring have been poorly documented but historically may have exceeded 750 Bcf (billion cubic feet or 21.2 billion cubic meters - $\mathrm{Bcm}$ ) annually [1].

There has, however, been a shift, in the global energy portfolio, with natural gas playing an expanding role. There are a number of reasons for this evolution. Natural gas is a

*Address correspondence to this author at the Chevron Energy Technology Company, 1500 Louisiana Street, Houston, TX 77002, USA; Tel: 1-832854-6989; Fax: 1-832-854-7018; E-mail: BarryKatz@Chevron.com "cleaner" fuel than either coal or oil. Transportation issues have decreased with the growth in both liquefied natural gas (LNG) and gas-to-liquids technology, including the development of floating LNG. There is a growing need for electrical generation using natural gas as the energy source in the developing world. Finally, there has been an expansion of the apparent resource-base, specifically unconventional resources (largely shale gas) in regions with very high energy demands such as the USA, Europe, and China.

As a consequence of the growing interest in natural gas, targeted exploration and research has been initiated to better define the attributes and processes of natural gas hydrocarbon systems, both conventional and unconventional. Unlike oil systems, there are multiple processes that may generate or produce natural gas. Natural gas may be produced thermally as a primary product through the decomposition of sedimentary organic matter or as a secondary product through the cracking of oil. In addition, natural gas may form through the microbial attack of sedimentary organic matter and/or previously buried coal seams and/or organic-rich shales that have been uplifted as well as through biodegradation of oil. The formation of abiogenic methane has been proposed through such 
processes as serpentization coupled with the hydration of mafic rocks [2], but their commercial significance has not been established.

The character of gas changes as a function of source character, formation mechanism or pathway, and extent of conversion. Natural gas may also undergo microbial alteration, changing both its molecular and isotopic character.

This paper focuses on part of the gas story and will provide a limited overview of the microbial gas resourcebase, the processes associated with formation of microbial gas accumulations, and the conditions that would favor microbial gas accumulation, how microbial processes may alter and potentially destroy gas accumulations. The term "microbial gas" rather than "biogenic gas" is used in this paper, as both microbial and thermogenic gas can ultimately be related to a biogenic source [3].

\section{MICROBIAL GAS RESOURCE-BASE}

In order to understand the resource-base, it is necessary to determine whether a gas accumulation is microbial, thermal or mixed. This is accomplished through an analysis of both molecular and isotope composition. Primary microbial gas is dry $\left(\mathrm{C}_{1} / \mathrm{C}_{2}+\mathrm{C}_{3}\right.$ is commonly greater than 1000 ; [4]), with methane generally accounting for $99+\%$ of the hydrocarbons present [5] and isotopically light $\left(\delta^{13} \mathrm{C}<-\right.$ $50 \%$ relative to the PDB standard; [3]). Secondary microbial gas displays much broader ranges in molecular and isotopic character and will be discussed in more detail later.

An examination of the literature suggests that the carbon isotope compositions of microbial gas in modern marine sediments may range from -110 to about $-50 \%$, with the majority of samples being between -90 and $-60 \%$ (Fig. 1). Methane carbon isotopic composition is a function of the nature of the active methanogenic population and growth conditions, including such factors as temperature and the isotopic composition of the carbon substrate [6]. For example, the methane carbon isotopic composition becomes enriched (i.e., heavier) with increasing temperature [6].

Microbial gas forms and is present in a number of surface and near surface settings as well as in the subsurface. Commonly cited environments for microbial gas occurrence and formation are presented in Table 1. These environments range from the intestinal track of termites and livestock to interstitial pore spaces in submarine settings. All of these settings share one factor in common - they are anoxic. Anoxia is required, at least at the microenvironmental level as methanogens are strict anerobes [7].

Views on the commercial significance of microbial gas have evolved over time. Rice and Claypool [8] suggested that about 20 percent of the global gas resource-base has a microbial origin. Granau [9] implied that an additional 10\% of the gas resource-base may also be microbial. Milkov [10] suggests that much of the global microbial gas resource-base is secondary, having been derived from preexisting hydrocarbon accumulations or organic-rich rocks (coals and/or organic-rich shales). Consequently the earlier estimates may be low. This underestimation of the microbial contribution is believed to be a result of their isotopic composition, such secondary gas accumulations display overlapping isotopic compositions with thermogenic gases.

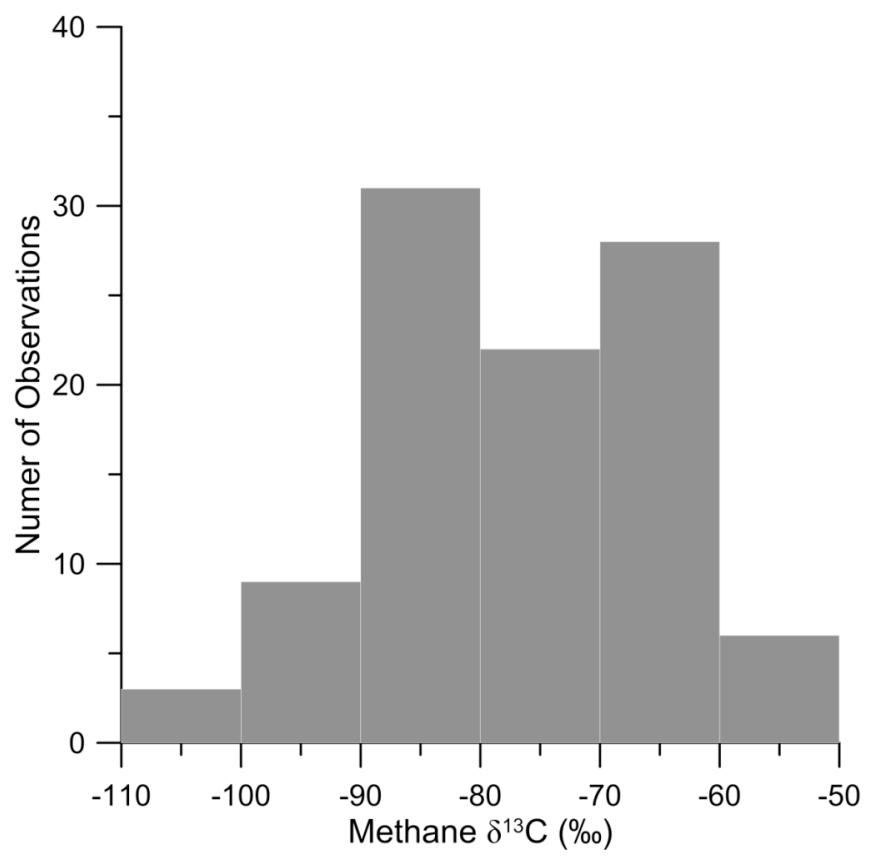

Fig. (1). Histogram of $\delta^{13} \mathrm{C}$ content of methane in modern marine sediments (data from various sources).

Table 1. Microbial Gas Settings

\begin{tabular}{|c|c|}
\hline Surface/Near-Surface & Subsurface \\
\hline \hline Rice paddies & Gas hydrates \\
\hline Marine sediments & Conventional reservoirs \\
\hline Animals/livestock & $\begin{array}{c}\text { Unconventional reservoirs (shale } \\
\text { gas and coalbeds) }\end{array}$ \\
\hline Termites & \\
\hline Landfills & \\
\hline Geothermal springs & \\
\hline Man-made waste digesters & \\
\hline
\end{tabular}

Individual microbial gas accumulations may be significant, exceeding $1 \mathrm{Tcf}$ ( $28 \mathrm{Bcm}$ - billion cubic meters; Table 2). Within specific regions microbial gas may dominate. For example, Mattavelli and Novelli [23] suggest that within Italy $74 \%$ of the gas reserves are microbial, with an additional $12 \%$ being mixed microbial-thermogenic.

The importance of the microbial resource-base has been underestimated because the microbial gas contribution to mixed gases has generally not been quantitatively assessed. One method to make such an assessment was proposed by Chung et al., [24]. This approach requires the isotopic composition of the co-generated thermogenic components $\left(\mathrm{C}_{2+}\right)$, the isotopic composition of the mixed methane component, and an assumed microbial end-member methane isotope composition (Fig. 2). Such an assessment was conducted by Katz et al., [25] for the Azeri sector of the South Caspian basin, where they examined 25 gas samples. The microbial contribution approached $60 \%$ and was 
typically between 10 and 40\% (Fig. 3). Vandré et al., [26] suggested an even broader range of microbial contributions $(15-95 \%)$ in the western Nile Delta. These data suggest that the microbial resource-base may have been significantly understated, when mixed gases are taken into consideration.

Table 2. Examples of Microbial Gas Fields with a Minimum Reserves of 1 Tcf $(28.3 \mathrm{Bcm})$

\begin{tabular}{|c|r|}
\hline Field & \multicolumn{1}{c|}{$\begin{array}{c}\text { Reserves } \\
\text { (Tcf/Bcm) }\end{array}$} \\
\hline \hline Agostino-Porto Garibaldi (Italy) & $3.5 / 99[11]$ \\
\hline Antrim Shale Resource Play (Michigan, USA) & $\sim 50 / 1420[12]$ \\
\hline Ballena Field (Colombia) & $1.2 / 34[13]$ \\
\hline Barbara Field (Italy) & $1.5 / 43[14]$ \\
\hline Chuchupa Field (Colombia) & $5.7 / 161[13]$ \\
\hline Kenai Field (Alaska, USA) & $2.25 / 64[15]$ \\
\hline Niengo Field (Indonesia) & $7-10 / 198-283[16]$ \\
\hline Raven Field (Egypt) & $4 / 113[17]$ \\
\hline Sebei-1 Field (China) & $95 / 2690[18]$ \\
\hline Southeast Alberta Gas Field (Canada) & $14 / 396[19]$ \\
\hline Tamar Field (Israel) & $8.4 / 238[20]$ \\
\hline Terang-Sirasun Field (Indonesia) & $1 / 28[21]$ \\
\hline Urengoy (Russia) & $220 / 6230[22]$ \\
\hline
\end{tabular}

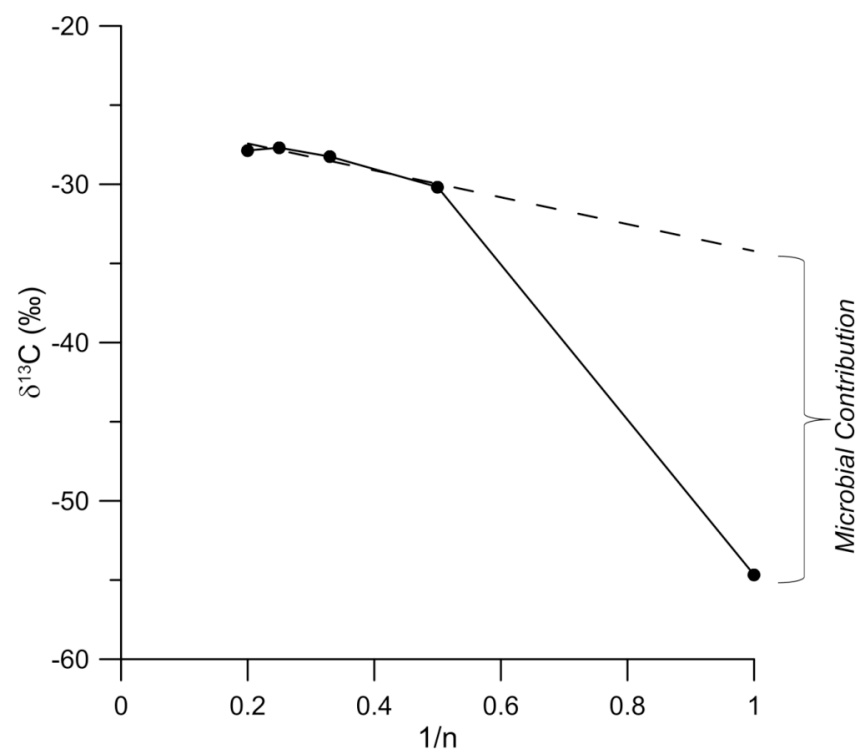

Fig. (2). Chung-type diagram used to estimate the biogenic contribution to a gas from the Karabagly field, South Caspian basin (data from [24]).

The microbial contribution to natural gas resources may have been further understated as a consequence of the importance of secondary microbial gas produced through the biodegradation of crude oil. The origins of these gases are not always as easily characterized as primary microbial gas, because their geochemical properties fall outside the ranges commonly associated with microbial gas $\left(\delta^{13} \mathrm{C}-55\right.$ to $-45 \%$; [27]). The importance of these secondary microbial gas accumulations should not be minimized. Milkov [22] suggests that the biodegradation of oil is at least partially responsible for the $220 \mathrm{Tcf}(6230 \mathrm{Bcm})$ gas accumulation of the Urgenoy field of western Siberia (Russia).

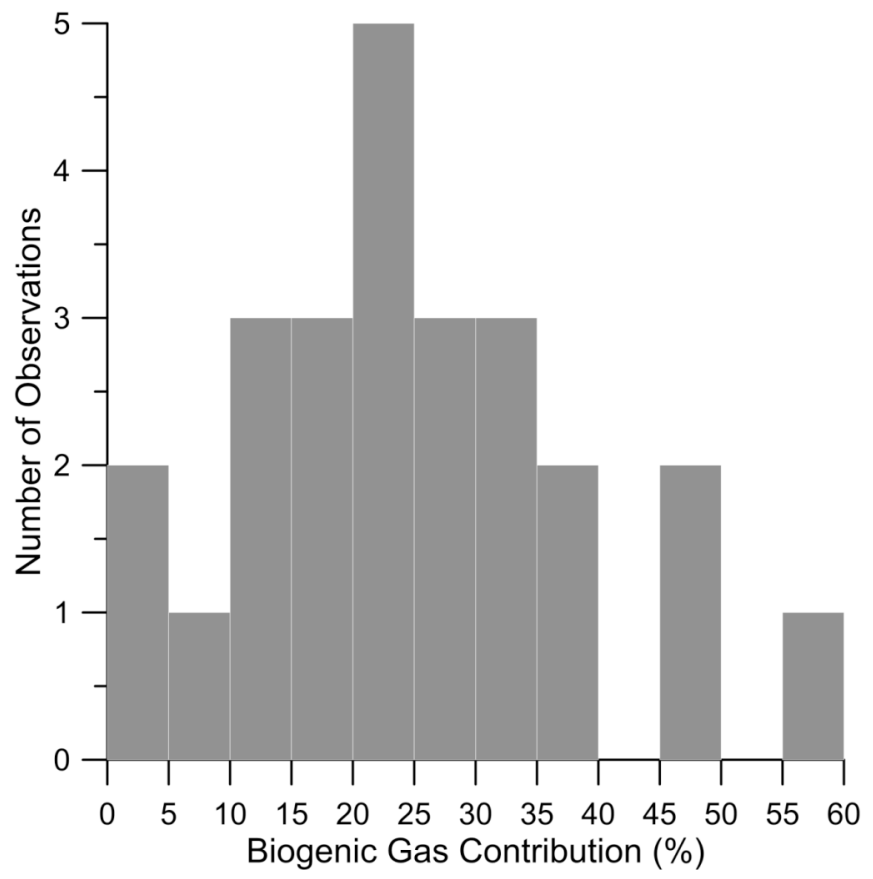

Fig. (3). Histogram of estimated microbial methane content of gas samples from fourteen fields in the South Caspian basin (data from [24]).

An examination of several known primary microbial gas accumulations can provide some guidance on the characteristics necessary for the formation of these fields. The first two examples are from offshore eastern Italy. The Agostino-Porto Garibaldi field is located in the northern Adriatic Sea. The estimated reserves for the field exceed 3.5 Tcf $(99 \mathrm{Bcm})$, distributed in 60 sands over 1600 meters of gross pay [11]. The PL2-L sand is one of the major reservoir sands, with gas reserves of $159 \mathrm{Bcf}(4.5 \mathrm{Bcm})$, and is capped by a thin clay of $\sim 0.6 \mathrm{~m}$. The trap formed through gentle folding penecontemporaneous with deposition. Vertical closure is about 100 meters, with the field covering about $50 \mathrm{~km}^{2}$. Mattavelli and Novelli [23] suggest that gas generation began during the Pliocene ( $\sim 3 \mathrm{Ma})$ and continues into the present. Current reservoir temperatures are between 48 and $63^{\circ} \mathrm{C}$.

The Barbara field is also located in the northern Adriatic Sea, with reserves of $\sim 1.5 \mathrm{Tcf}(42 \mathrm{Bcm})$ of microbial gas [14]. This gas is contained within 13 Pleistocene turbidite sandstone units intercalated within claystones [11]. The trap itself is a gentle drape anticline covering $\sim 80 \mathrm{~km}^{2}$, with approximately $50 \mathrm{~m}$ of closure.

The Kenai field is located in southern Alaska's (USA) Cook Inlet basin. The sedimentary section ranges from Jurassic through the Quaternary [28]. Isotope data [29] suggest that reservoirs contain biogenic and thermogenic gas. The Kenai field is a simple anticline. The only major fault is located at the field's northern end, isolating it from the Cannery Loop field [30]. The microbial gas reserves are contained within five shallow pools, with an average pay thickness of $\sim 160 \mathrm{~m}$. The principal microbial gas reservoir is 
the Plio-Pleistocene Sterling Formation, where cumulative production has exceeded 1.7 Tcf $(48 \mathrm{Bcm})$ [30]. Lesser production is associated with the Beluga, Upper Tyonek, and Lower Tyonek Formations. Reservoir depths are less than 1500 meters, with reservoir temperatures of about $43^{\circ} \mathrm{C}$.

A synthesis of the geologic data from these and other fields, which represent primary microbial gas accumulations, suggest that these exploration opportunities are associated with geologically simple structures that formed during or soon after deposition. The reservoirs tend to be young (Neogene); examples of older reservoirs exist, but in these cases gas generation appears to be Neogene or Recent. Reservoir temperatures are commonly between 40 and $45^{\circ} \mathrm{C}$, although the reservoir temperature range maybe significantly broader. When reservoir temperatures exceed $\sim 60^{\circ} \mathrm{C}$, the gas most likely represents a paleo-accumulation, which formed at shallower depths and has subsequently been buried.

Migration history is also a major factor in controlling primary microbial gas accumulation. Brown [31] suggests that in situ generation is insufficient to explain commercial biogenic gas accumulations and that a combination of vertical and lateral migration is needed to gather sufficient gas for an accumulation to become commercial. He adds that for such migration to occur, sufficient gas generation within the fetch area and the appropriate PVT conditions must exist for bubble formation (i.e., a free gas phase is required).

A similar assessment for secondary microbial gas accumulations is not as simple because of the broader set of conditions under which they form - biodegradation of preexisting oil accumulations $[10,22]$ and the bacterial alteration of coal [32] or organic-rich shale [33, 34]. Milkov [10] in his review of secondary microbial accumulations derived through biodegradation of preexisting oil suggests that there are some common geologic characteristics. These include shallow reservoir depths $(<1850 \mathrm{~m})$ and temperatures of about $70^{\circ} \mathrm{C}$ or less. Most of these reservoirs were also found to be Cenozoic sandstones. Many of the secondary accumulations associated with coal and organic-rich shales may be classified as unconventional resources. These accumulations tend to be associated with basin margins where meteoric waters can reintroduce bacteria into the subsurface through faults, fractures, and joint networks.

\section{MICROBIAL GAS GENERATION}

Microbial gas generation is a strictly anerobic process [7, 35]. Methanogenesis represents the terminal biochemical decomposition stage [36]. Methanogenesis can occur through several processes, but is generally represented as either $\mathrm{CO}_{2}$ reduction or as acetate fermentation [37] (Fig. 4).

$$
\begin{aligned}
& \mathrm{CO}_{2}+4 \mathrm{H}_{2} \rightarrow \mathrm{CH}_{4}+2 \mathrm{H}_{2} \mathrm{O}\left(\mathrm{CO}_{2}\right. \text { reduction) } \\
& \mathrm{CH}_{3} \mathrm{COOH} \rightarrow \mathrm{CH}_{4}+\mathrm{CO}_{2} \text { (acetate fermentation) }
\end{aligned}
$$

The methanogenic process that dominates is controlled by a number of factors including nutrient availability and the quality and quantity of organic matter [38]. Although there are some exceptions, of the two processes $\mathrm{CO}_{2}$ reduction appears to be the more significant mechanism when commercial accumulations are catalogued. Geochemically the relative importance of the two processes can be determined through an examination of deuterium. Hydrogen isotope fractionation is greater for acetate fermentation due to the transfer of a methyl group which is depleted in deuterium and accounts for three quarters of the hydrogen in methane [37].

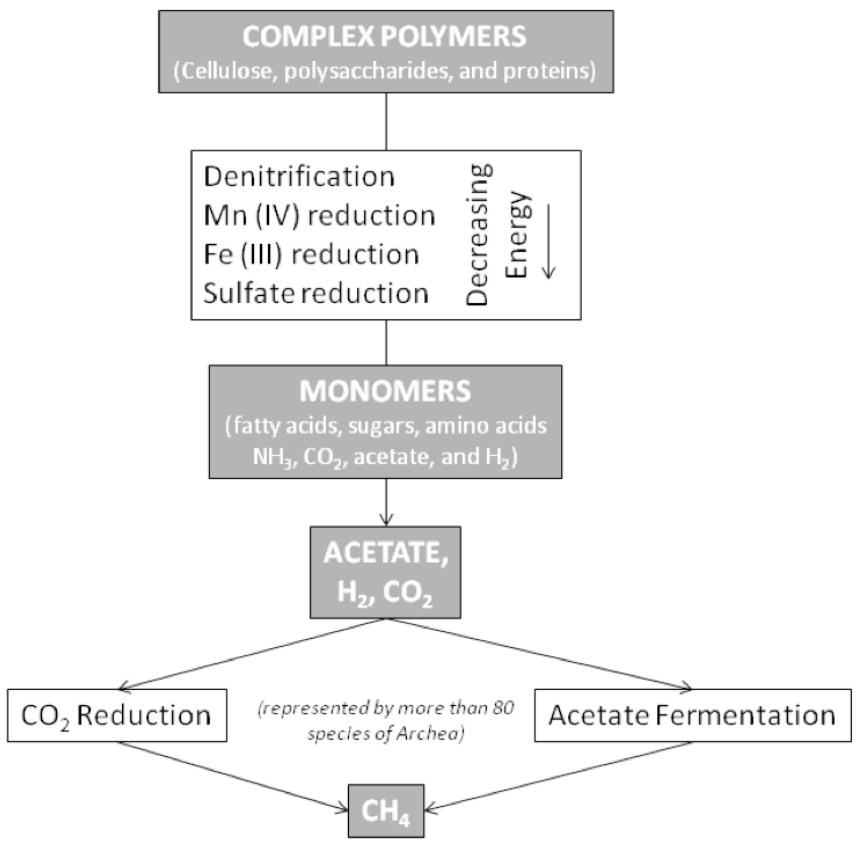

Fig. (4). Schematic representation of methanogenesis pathways.

Methanogenesis is accomplished by more than 80 species of Archea [35]. Some of these species (e.g., Methanobacterium barkeri and Methanobacterium formicium) are capable of utilizing multiple methanogenic pathways [39]. Methanogens are unable to directly utilize the larger molecules such as cellulose, polysaccharides, and proteins that may be incorporated into sediments. These large complex molecules need to be broken down to smaller compounds and eventually acetate, $\mathrm{H}_{2}$ and $\mathrm{CO}_{2}$, through a sequence of microbial processes including denitrification, manganese, iron, and sulfate reduction. Wolin and Miller [40] suggest that methanogens have developed a "communal strategy", in which the waste products of one community become the substrate for another. It has also been suggested that the substrates for methanogenesis may be produced within mudstones, where organic matter is relatively enriched, and that the methanogenesis itself may occur within associated sands and silts, where greater pore space could accommodate larger methanogen populations [41].

Although there is a tendency to assume that microbial gas is exclusively methane, there is evidence for ethanogenesis and propanogenesis [42, 43, 44]. It is believed that the organisms responsible for these processes rely largely on acetate and therefore must compete with aceticlastic methanogens [43]. Ethanogens and propanogens are less competitive and hence contribute less gas to accumulations than the methanogens. Little conclusive microbial ethane and propane carbon isotope data have been published and some published data may actually represent incipient or low temperature thermogenic gas [45]. Small concentrations of microbially produced ethane recovered from a shallow aquifer associated with leaking wells have been identified through its isotopically light carbon character ranging from 73 to $-45.4 \%$ o [44]. Isotopically heavier values for what is thought to be microbial ethane $\left(\delta^{13} \mathrm{C} \sim-46\right.$ to $\left.\sim-15 \%\right)$ and 
propane $\left(\delta^{13} \mathrm{C} \sim-25\right.$ to $\sim 9 \%$ ) have been reported by Hinrichs et al., [43] and Oremland et al., [42] $\left(\delta^{13} \mathrm{C}_{\text {ethane }}-55\right.$ to $-35 \%$ ). They conclude a microbial origin because of the low temperatures associated with the sampling locations.

There are a number of factors that control the rate of methanogenesis. Key among these factors is temperature [46]. Peak microbial activity occurs between 35 and $45^{\circ} \mathrm{C}$ (mesophiles). In addition to the mesophiles, there also exist psychrophiles and thermophiles (Fig. 5). Neither the psychophiles or thermophiles are considered important to the formation of commercial gas accumulations. Much of the gas produced by the psychophiles would form prior to seal development. Thermophilic methanogens would produce much of their hydrocarbons coincident with the onset of thermogenic hydrocarbon generation, which would be the dominate gas formation process.

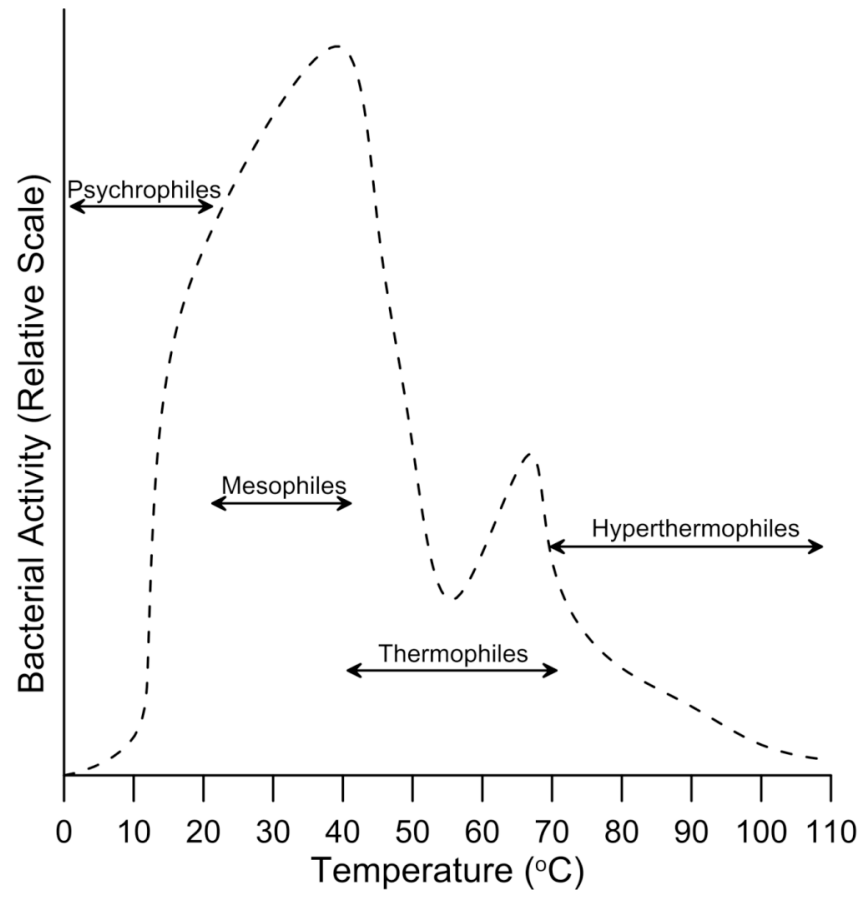

Fig. (5). Relative methanogen activity level as a function of temperature.

Another key control is the availability of sulfate in the pore waters. Methanogenesis requires that sulfate be absent or present at very low concentrations [47]. Although there has been considerable discussion as to why the near absence of sulfate is required, it is now generally believed that the methanogens are less energy efficient relative to the sulfate reducers and are thus unable to effectively compete $[48,49]$.

Other factors that are known to influence the rate of methanogenesis include pore water salinity [50], $\mathrm{pH}$ [51], and pore space [52]. At elevated salinities methanogenic activity may be inhibited [53]. Sufficient pore space needs to be present for the microbial population to grow. It is interesting to note that although the abundance of substrate can impact total gas yield it does not appear to control rate [52].

Work by Clayton [54] suggests that a cubic meter of sediment containing $1 \%$ total organic carbon will, under optimum conditions, yield approximately $4.9 \mathrm{~m}^{3}\left(\sim 173 \mathrm{ft}^{3}\right)$ of gas. This is equivalent to the conversion of about $10 \%$ of the organic matter. The overall yield is controlled by heating rate, a function of geothermal gradient, and sedimentation rate. Absolute microbial gas yield is reduced as the heating rate increases as a consequence of the reduced time experienced by the source within the zone associated with peak microbial activity decreases.

Schlegal et al., [55] indicate that under the appropriate conditions, the rate of microbial gas production can be sufficient that economic accumulations may form in less than 100,000 years. They suggest, for example, that within the New Albany Shale (Illinois basin, USA), microbial methane production rates range from 10 to $1000 \mathrm{Tcf} / \mathrm{Ma}(28$ to $2800 \mathrm{Bcm} / \mathrm{Ma}$ ). Although these values appear large, Schlegal et al., [55] note that they are several orders of magnitude less than observed in laboratory experiments. In western Canada, Cokar et al., [56] report that gas generation within the Colorado Group shales is actually greater to or equal to that of production.

\section{MICROBIAL GAS CHARACTERIZATION AND PROPERTIES}

There are two "types" of microbial gas: primary gas formed as part of the initial diagenetic sequence of sedimentary organic matter and secondary microbial gas. Secondary microbial gas is formed during the biodegradation of oil within conventional reservoirs or through the microbial attack of disseminated bitumen and/or possibly labile kerogen in coals or organic-rich shales. In the case of microbial gas formed in coals and organic-rich shales postburial introduction of a microbial community capable of both solubilizing larger more complex organic molecules and performing methanogenesis is required [57]. The term secondary microbial gas was introduced by Bernard et al., [58] and Scott et al., [32]. These two gas "types" have different geochemical attributes and conditions of formation than primary microbial gas.

Primary microbial gas displays those characteristics commonly attributed to microbial gas deposits. Their carbon isotope compositions are light, displaying methane $\delta^{13} \mathrm{C}$ values between -110 and $-50 \%$ and $\delta \mathrm{D}$ values from -450 to $150 \%$ [3]. Microbial gas derived via $\mathrm{CO}_{2}$ reduction displays $\delta^{13} \mathrm{C}$ values between -110 and $-55 \%$ and $\delta \mathrm{D}$ values between -250 and $-150 \%$. Gas produced through acetate fermentation displays somewhat overlapping and slightly heavier $\delta^{13} \mathrm{C}$ values of -70 to $\sim-50 \%$, and lighter $\delta \mathrm{D}$ values, -450 to $250 \%$. Gases produced by both processes are dry, where ethane content is typically less than $0.2 \%$.

In contrast, secondary microbial gas displays a much more variable $\delta^{13} \mathrm{C}$ content, which often overlaps with what may typically be considered representative of thermal gas $\left(\delta^{13} \mathrm{C}-55\right.$ to $-35 \%$; [10]). A key for identification of secondary microbial gas is its common association with isotopically heavy $\mathrm{CO}_{2}$, with $\delta^{13} \mathrm{C} \mathrm{CO}_{2}$ values greater than $10 \%$ and often exceeding 2\%o [10]. These $\delta^{13} \mathrm{C}$ enriched isotope values may reflect that secondary microbial gas is formed mostly though $\mathrm{CO}_{2}$ reduction.

The geologic settings and conditions associated with these different gases are also distinct. Primary gas forms soon after sediment deposition, with the microbial population most probably being introduced at the time of or soon after deposition. Primary microbial gas accumulations 
are generally associated with rapid sedimentation and lower geothermal gradients. As a consequence of early gas generation, primary microbial gases are found in early formed structures. There is also a tendency for these traps to be geologically simple, such as drapes and four-ways and are not fault dependent. Stratigraphic traps may also exist. The potential gas available is dependent on the amount of organic matter present in the fetch area and the heating history.

The conditions of formation of secondary gas accumulations are quite different. The primary control for these secondary gas accumulations is the availability of an oil pool that can be biodegraded or the presence of coal and/or organic-rich shales that have been uplifted and exposed to the influx of meteoric water.

Secondary microbial gas generation through oil field biodegradation may partially explain the association of dry gas caps with heavily biodegraded oils [27]. Biodegradation is limited to reservoirs that have never exceeded $80^{\circ} \mathrm{C}$ [60] and display a well defined oil-water contact [59]. Crude oil biodegradation produces organic acids [61] and $\mathrm{CO}_{2}$ [62], which may be utilized by the methanogens. If an oil pool experiences temperatures in excess of $80^{\circ} \mathrm{C}$ it is effectively sterilized, preventing biodegradation from proceeding. Reservoirs that have experienced elevated temperatures do not appear to be capable of undergoing biodegradation, even if there is uplift and exposure to cooler temperatures [59]. This is thought to indicate that the reintroduction of a microbial community through the influx of meteoric water is not significant [60]. When the secondary microbial gas is derived from a preexisting oil pool there is no requirement for a conventional "source rock", because the oil provides the substrate and the gas essentially forms in situ.

The processes associated with secondary microbial gas formation in either coal seams and organic-rich shales appear different from those associated with oil biodegradation. These accumulations are heavily dependent on basin hydrology [32]. In these settings the introduction of meteoric fresh water through a permeable fracture network following uplift is critical [33]. Unlike in the case of the biodegraded oil field discussed above, meteoric water influx provides the means to reintroduce a significant active microbiological community into the subsurface. The permeability and fracture network is anisotropic and can vary significantly making the generation of gas also variable within an individual resource play. The need to introduce meteoric water into the system largely explains the restriction of microbial gas accumulations to the margins of the Michigan (Antrim Shale) and Illinois (New Albany Shale) basins, as well geographic differences in gas content within these shale units [34] and the Fruitland coals of the San Juan basin (Colorado and New Mexico; [32]). This was also noted by Hoşgörmez [63] for the Carboniferous coal-bearing sequence of the Zonguldak basin. Here the amount of microbial gas present is controlled by cleat/fracture intensity. Microbial gas formation within these unconventional reservoirs is dependent on the nature of the organic matter and level of thermal maturity of the rock prior to the reintroduction of the microbial community; these units need to have achieved maturity levels consistent with late diagenesis or the oilwindow so that bitumen and/or oil has been generated. Any possible kerogen contribution to microbial gas is contingent on the potential for microbial or bio-solubilzation. And, as with primary microbial gas formation, this solubilization is dependent on a different microbial community than the methanogens.

As a consequence of an oil pool acting as the source or a need for the unconventional reservoir to achieve a more advanced level of thermal maturity, secondary microbial gas accumulations form late in a basin's history, when trap complexity can be greater than that associated with primary microbial gas.

\section{SYSTEM EFFICIENCY}

The availability of hydrocarbon charge is only partially controlled by gas generation through either thermal or microbial processes. Another controlling factor is the overall system efficiency, which accounts for expulsion, secondary migration, and any remigration that has occurred, as well as potential losses from the system. These losses include surface seepage, trap bypass, poor relative timing (i.e., generation precedes trap development), as well as hydrocarbons lost to solution. Free gas will not be available until pore fluids, oil and water, are saturated [64]. Clayton [54] suggested that $\sim 0.2 \%$ organic carbon is required to saturate the source rock pore network with gas.

There have been few studies examining overall gas system efficiency. One such study had been performed by Katz and Williams [65]. These authors examined the microbial gas system of the Guajira region, Colombia. The produced gases studied were greater than $98.5 \%$ methane, with $\delta^{13} \mathrm{C}$ values less than $-54 \%$. The gas volume generated within the fetch areas for five fields was determined and compared with the reported gas in-place. These comparisons suggest that between 0.75 and $3.25 \%$ of the microbial gas generated was actually trapped. Although these efficiencies are low, they still may be slightly inflated due to the presence of a possible thermogenic contribution. Since the work of Katz and Williams [65], there have been some published gas seep isotope data from the region [13], suggesting that the presence of a small thermogenic gas contribution was not taken into consideration in the original efficiency estimate. Rangel et al., [13] reported soil gas sample data from the area, with $\mathrm{C}_{2+}$ components exceeding $10 \%$ and methane $\delta^{13} \mathrm{C}$ values as heavy as $-45 \%$. Such a thermogenic gas contribution would reduce the microbial gas in-place and therefore the estimated system efficiency.

System efficiency or generation potential may not be the explanation for why many microbial gas traps are not filled to spill. Brown [34] suggests that the lack of fill to spill may be a result of post-accumulation compression. He argues that because much of the microbial gas is generated and accumulated at relatively shallow depths (less than $1 \mathrm{~km}$ ) and subsequently buried to greater depths, the gas undergoes compression leading to under-filled traps. He notes that this late stage compression is not a problem for later stage thermal gas, because of a more limited change in postcharging reservoir PVT conditions.

\section{BIODEGRADATION}

Just as oil may undergo biodegradation, gas accumulations may also be biodegraded [66]. The geologic conditions for gas biodegration are essentially the same as 
those for oils with respect to both temperature and the need for a water leg. The same microbial populations need not, however, be active in both oil and gas reservoirs or oil and gas legs within a single reservoir [66].

The biodegradation of a wet gas results in a number of changes in molecular and isotopic composition. There is preferential removal of propane, with $n$-butane and $n$ pentane being less susceptible, and ethane being the most resistant [66]. Larter et al., [67] suggest that this may be a function of propane's greater water solubility, making it more readily attackable. From these compounds, the isotopically lighter components are preferentially removed, resulting in isotopically heavier propane, $n$-butane and $n$ pentane (Fig. 6). The relationship between $n$-butane concentration and $\delta^{13} \mathrm{C}$ content observed on a suite of gases from the South Caspian basin suggests the impact of biodegradation on gas character (Fig. 7). This isotope enrichment occurs in both carbon and hydrogen [10]. Initially iso-butane and iso-pentane are largely unaltered. The loss of the wet gas compounds increases dryness to such a degree that the origin of the gas may be misinterpreted (i.e., the gas may appear to have a thermogenic origin). The loss of wet gas components and the formation of additional methane through biodegradation of oil may further aid in explaining the presence of dry gas caps overlying biodegraded oil pools when both gas and oil biodegradation have been active [67].

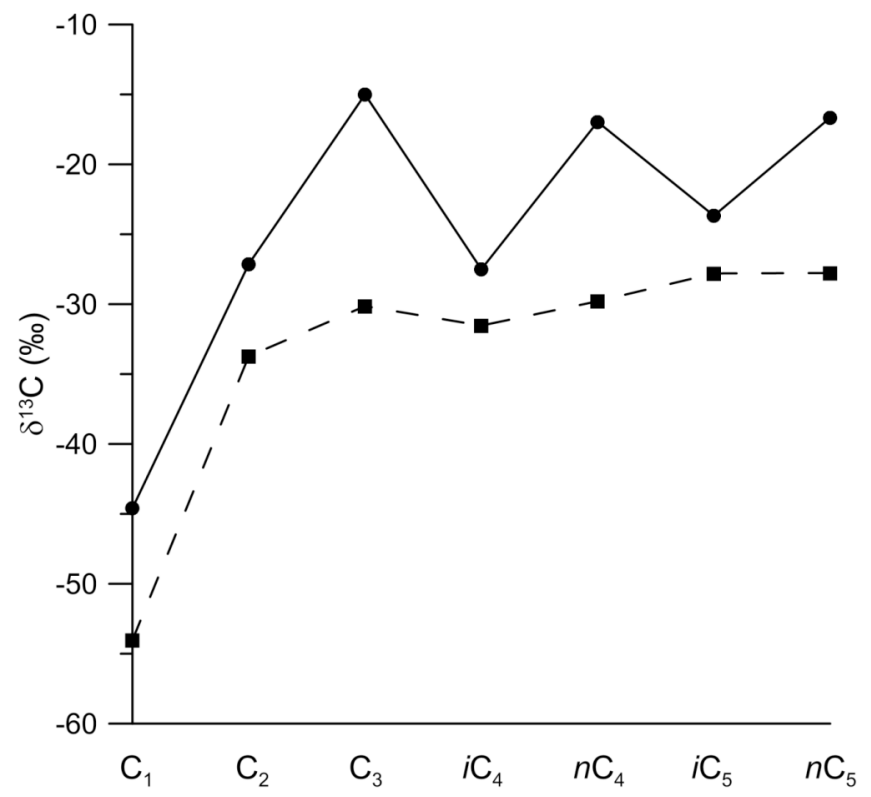

Fig. (6). Carbon isotope composition of biodegraded (solid line Guneshli \#155) and non-biodegraded (dashed line - Mishovdag \#372) gases from the South Caspian basin (data from [24]).

Methane can also be microbially oxidized but is much more difficult to detect [66]. Methane oxidizing bacteria fractionate both carbon and hydrogen. The residual methane is isotopically enriched in both species compared to the original methane $[3,68]$. Although this is known to occur within the water column, Schoell [69] suggests that methane oxidation to any significant degree in commercial reservoirs is unlikely.

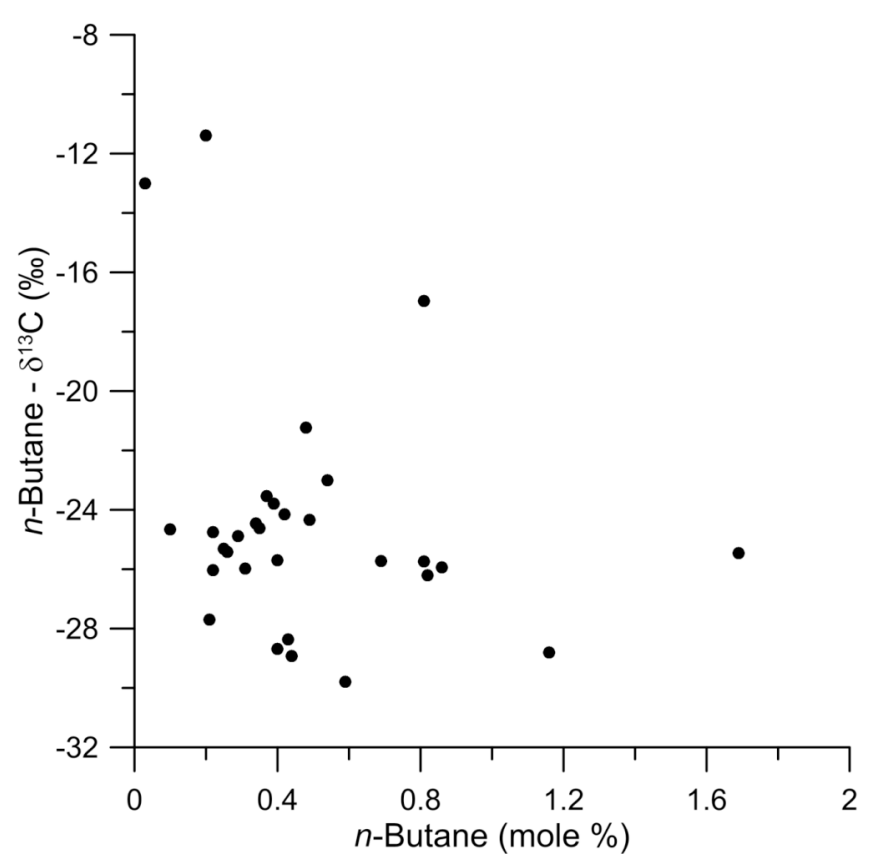

Fig. (7). Relationship between abundance of butane and butane $\delta^{13} \mathrm{C}$ content of South Caspian basin gases (data from [24]).

\section{SUMMARY AND CONCLUSIONS}

- Microbial processes are responsible for the formation, alteration, and destruction of some natural gas accumulations.

- $\quad$ Primary and secondary microbial gas accounts for more than 20 percent of the global resource-base and may dominate in specific regions. As a result of mixing and the presence of secondary microbial gas, published resource volumes may have been underestimated.

- There are multiple pathways for methanogenesis, including $\mathrm{CO}_{2}$ reduction and acetate fermentation.

- $\quad$ Microbial gases are dry, but small quantities of ethane and propane may also be formed through microbial processes.

- $\quad$ Primary microbial gas is characterized by its dryness and isotopically light character. Secondary microbial gas is much more variable in character, but is associated with isotopically heavy $\mathrm{CO}_{2}$.

- Primary microbial gas accumulations require an anoxic setting, high rates of sedimentation, low geothermal gradiants, early trap formation, low temperatures, and limited sulfate. Secondary microbial gas accumulations require either that an oil pool undergoes biodegradation or that a coal seam or organic-rich shale be uplifted, fractured, and subjected to meteoric water influx to reintroduce a microbial community.

- Gas accumulations may be degraded. Biodegradation results in isotopically heavier propane, butane, and pentane. There is also an increase in gas dryness. These changes often complicate the assessment of a gas' origin and thermal maturity. 


\section{ACKNOWLEDGEMENTS}

This work was originally presented at the AAPG Hedberg Research conference on natural gas organized by Drs. Shuichang Zhang and Yongchun Tang. An early version of this manuscript was improved through the comments by Drs. Fang Lin and Melanie Everett. The author thanks Chevron for permission to present and publish this work.

\section{CONFLICT OF INTEREST}

None declared.

\section{REFERENCES}

[1] World Bank. GGFR: The New Flares Newsletter Issue 8, JanuaryJune 2009. 2009; pp. 4.

[2] Sherwood Lollar B, Frape SK, Weise SM, Fritz P, Macko SA, Welhan JA. Abiogenic methanogenesis in crystalline rocks. Geochim Cosmochim Ac 1993; 57:5087-97.

[3] Whiticar MJ. Carbon and hydrogen isotope systematic of bacterial formation and oxidation of methane. Chem Geol 1999; 161: 291314.

[4] Bernard BB, Brooks JM, Sackett WM. Natural gas seepage in the Gulf of Mexico. Earth Planet Sci Lett 1976; 31: 48-54.

[5] Rice DD. Biogenic gas: Controls, habitats, and resource potential. In: Howell DG, Wiese K, Fanelli M, Zink LL, Cole F, Eds. The Future of Energy Gases. USGS Prof Pa 1993; 1570: 583-606.

[6] Botz R, Pokojski HD, Schmitt M, Thomas M. Carbon isotope fractionation during bacterial methanogenesis by $\mathrm{CO}_{2}$ reduction. Org Geochem 1996; 25: 255-62.

[7] Zeikus JG. The biology of methanogenic bacteria. Bacterio Rev 1977; 41:514-41.

[8] Rice DD, Claypool GE. Generation, accumulation, and resource potential of biogenic gas. AAPG Bull 1981; 65: 5-25.

[9] Granau HR. Natural gas in major basins worldwide attributed to source type, thermal maturity and bacterial origin. Proceedings of the $11^{\text {th }}$ World Petroleum Congress 1984; 2: 293-302.

[10] Milkov AV. Worldwide distribution and significance of secondary microbial methane formed during petroleum biodegradation in conventional reservoirs. Org Geochem 2011; 42: 184-207.

[11] Mattavelli L, Pieri M, Groppi G. Petroleum exploration in Italy: A review. Mar Petrol Geol 1993; 10: 410-25.

[12] Kuuskra VA, Wicks DE, Thurber JL. Geologic and reservoir mechanisms controlling gas recovery from the Antrim Shale. $67^{\text {th }}$ Annual Technical Conference and Exhibition of the Society of Petroleum Engineers 1992; pp. 209-24.

[13] Rangel A, Katz B, Ramierz V, dos Santos Neto EV. Alternative interpretations as to the origin of the hydrocarbons of the Guajira basin, Colombia. Mar Petrol Geol 2003; 20: 129-39.

[14] Ianniello A, Bolelli W, Di Scala L. Barbara field, Adriatic Sea, offshore Italy: A giant gas field masked by seismic velocity anomaly - a subtle trap. In: Halbouty, MT, Ed. Giant Oil and Gas Fields of the Decade 1978-1988. AAPG Memoir 1992; 54: 265-76.

[15] Blasko DP. Natural gas fields - Cook Inlet basin, Alaska. US Bureau of Mines Open File Report 1974; 35-74: p. 24.

[16] Rubens-Muhammad R, Baldwin V. Irian Jaya stranded gas accumulation revived after 42 years. http://www.pennenergy.com/ index/petroleum/display/70969/articles/offshore/volume-60/issue4/news/exploration/irian-jaya-stranded-gas-accumulation-revivedafter-42-years.html, 2010.

[17] Whaley J. The Raven field: Planning for success. GEO ExPro 2008; 5(1): 36-40.

[18] Dang Y, Zhao W, Zhang S et al. Biogenic gas systems in eastern Qaidam basin. Mar Petrol Geol 2008; 25; 344-56.

[19] Canadian Gas Potential Committee. Natural gas potential in Canada. Canadian Gas Potential Committee 1977 (unpaginated).

[20] Cunningham S. Tamar - The opening of a frontier basin in the eastern Mediterranean. American Association of Petroleum Geologists Annual Convention and Exhibition 2011.

[21] Noble RA, Henk FH Jr. Hydrocarbon charge of a bacterial gas field by prolonged methanogenesis: An example from the East Java Sea, Indonesia. Org. Geochem 1998; 29: 301-14.

[22] Milkov AV. Methanogenic biodegradation of petroleum in the West Siberian Basin (Russia): Significance for formation of giant Cenomanian gas pools. AAPG Bull 2010; 94: 1485-541.
[23] Mattavelli L, Novelli L. Geochemistry and habitat of natural gas in Italy. Org Geochem 1988; 13: 1-13.

[24] Chung HM, Gormly JR, Squires RM. Origin of gaseous hydrocarbon in subsurface environments: Theoretical considerations of carbon isotope distribution. Chem Geol 1988; 71 : 97-103.

[25] Katz BJ, Narimanov A, Huseinzadeh R. Significance of microbial processes in gases of the South Caspian basin. Mar Petrol Geol 2002; 19: 783-96.

[26] Vandré C, Cramer B, Gerling P, Winsemann J. Natural gas formation in the western Nile delta (Eastern Mediterranean): Thermogenic versus microbial. Org Geochem 2007; 38: 523-39.

[27] Jones DM, Head IM, Gray ND, et al. Crude-oil biodegradation via methanogenesis in subsurface petroleum reservoirs. Nature 2008; 451: 176-81.

[28] Kelly TE. Geology and hydrocarbons in Cook Inlet basin, Alaska. In: Childs OE, Beebe BW, Eds. Backbone of the Americas. AAPG Memoir 1963; 2: 278-96.

[29] Claypool GE, Threlkeld CN, Magoon LB. Biogenic and thermogenic origins of natural gas in Cook Inlet basin, Alaska. AAPG Bull. 1980; 64: 1131-9.

[30] Brimberry DL, Gardner PS, McCullough ML, Trudell SE. Kenai field, the Kenai Peninsula's largest gas field. In: Dallegge TA, Ed. 2001 Guide to the petroleum, geology, and shallow as potential of the Kenai Peninsula, Alaska. State of Alaska Department of Natural Resources 2001; pp. 20-8.

[31] Brown A. Migration controls on the occurrence of economic bacterial gas accumulations. $5^{\text {th }}$ Inst Study Earth \& Man Uncony Methods in Explor for Petrol \& Natur Gas Symp 1997; pp. 84-106.

[32] Scott AR, Kaiser WR, Ayers WB Jr. Thermogenic and secondary biogenic gases, San Juan basin, Colorado and New Mexico Implications for coal bed producibility. AAPG Bull 1994; 78: 1186-209.

[33] Martini AM, Walter LM, Ku TCW, Budai JM, McIntosh JC, Schoell M. Microbial production and modification of gases in sedimentary basins: A geochemical case study from a Devonian shale gas play, Michigan basin. AAPG Bull 2003; 87: 1355-75.

[34] Martini AM, Walter LM, McIntosh JC. Identification of microbial and thermogenic components from Upper Devonian black shale cores, Illinois and Michigan basins. AAPG Bull 2008; 92: 327-39.

[35] Liu Y, and Whitman WB. Metabolic, phylogenetic, and ecological diversity of methanogenic archaea. Ann NY Acad Sci 2008; 1125: 171-89.

[36] Ferry JG, Lessner DJ. Methanogenesis in marine sediments. Ann N Y Acad Sci 2008; 1125: 147-157.

[37] Whiticar MJ, Faber E, Schoell M. Biogenic methane formation in marine and freshwater environments: $\mathrm{CO}_{2}$ reduction $v s$ acetate fermentation - Isotopic evidence. Geochim Cosmochim Ac 1986; 50: 693-703.

[38] Bates BL, McIntosh JC, Lohse KA, Brooks PD, Influence of groundwater flowpaths, residence times and nutrients and the extent of microbial methanogenesis in coal beds: Powder River basin USA. Chem Geol 2011; 284: 45-61.

[39] Bryant NP, Tzeng SF, Robinson IM, Joyner, AE Jr. Nutrient requirements of methanogenic bacteria. In: Pohlard FG, Ed. Anaerobic Biological Treatment. American Chemical Society, Adv Chem Seri 1971; 105: 11-22.

[40] Wolin MJ, Miller TL. Bioconversion of organic carbon to $\mathrm{CH}_{4}$ and $\mathrm{CO}_{2}$. Geomicrobiology 1987; 5: 239-59.

[41] McMahon PB, Chapelle FH, Fells WF, Bradley PM. Role of microbial processes in linking sandstone diagenesis with organicrich clays. J Sediment Petrol 1992; 62: 1-10.

[42] Oremland RS, Whiticar MJ, Strohmaier FE, Kiene RP. Bacterial ethane formation from reduced, ethylated sulfur compounds. Geochim Cosmochim Ac 1988; 52: 1895-904.

[43] Hinrichs K-U, Hayes JM, Bach W et al. Biological formation of ethane and propane in the deep marine subsurface. P Natl Acad Sci USA 2006; 103: 14684-9.

[44] Taylor SS, Sherwood Lollar B, Wassenar LI. Bacteriogenic ethane in near surface aquifers: Implications for leaking hydrocarbon well bores. Environ Sci Technol 2000; 34: 4727-32.

[45] Leythaeuser D, Schaefer RG, Cornford C, Weiner B. Generation and migration of light hydrocarbons $\left(\mathrm{C}_{2-7}\right)$ in sedimentary basins. Org Geochem 1979; 1: 191-204.

[46] Belyaev SS, Wolkin R, Kenealy WR, DeNiro MJ, Epstein S, Zeikus JG. Methanogenic bacteria from the Bonduzhskoe oil field: 
General characterization and analysis of stable-carbon isotopic fractionation. Appl Environ Microb 1983; 45: 691-7.

[47] Winfrey MR, Zeikus JG. Effect of sulfate on carbon and electron flow during microbial methanogenesis in freshwater. Appl Environ Microbiol 1977; 33: 275-81.

[48] Oremland RS, Taylor BF. Sulfate reduction and methanogenesis in marine sediments. Geochim Cosmochim Ac 1978; 42: 209-14.

[49] Lovley DR, Klug MJ. Model for the distribution of sulfate reduction and methanogenesis in freshwater sediments. Geochim Cosmochim Ac 1986; 50: 11-8.

[50] Waldron PJ, Petsch ST, Martini AM, Nüsslein K. Salinity constraints on subsurface archaeal diversity and methanogenesis in sedimentary rock rich in organic matter. Appl Environ Microb 2007; 73: 4171-9.

[51] Visser A, Gao Y, Lettingam G., Effects of $\mathrm{pH}$ on methanogenesis and sulphate reduction in thermophilic $\left(55^{\circ} \mathrm{C}\right)$ UASB reactors. Bioresource Technol 1993; 44: 113-21.

[52] Chapelle FH, Lovley DR. Rates of microbial metabolism in deep coastal plain aquifers. Appl Environ Microb 1990; 56: 1865-74.

[53] Zindler SH. Physiological ecology of methanogens. In: Ferry JG, Ed. Methanogenesis: Ecology, Physiology, Biochemistry and Genesis. Chapman and Hall 1993; pp. 128-206.

[54] Clayton C. Source volumetrics of biogenic gas generation. In: Vially R, Ed. Bacterial Gas, Editions Technip 1992; pp.191-204.

[55] Schlegel ME, Zhou Z, McIntosh J, C. J. Ballentine CJ, Person MA. Constraining the timing of microbial methane generation in an organic-rich shale using noble gases, Illinois basin, US. Chem Geol 2011; 287: 27-40.

[56] Cokar M, Kallos MS, Huang H, Larter SSR, Gates ID. Biogenic gas generation from shallow organic matter-rich shales. Proceedings Canadian Unconventional Resources \& International Petroleum Conferences CSUG/SPE 135323 2010; pp. 12.

[57] Brown A. Identification of source carbon for microbial methane in unconventional gas reservoirs. AAPG Bull 2011; 95: 1321-38.

[58] Bernard FP, Connan J, Magot M. Indigenous microorganisms in connate water of many oil fields: A new tool in exploration and production techniques. Proceedings $67^{\text {th }}$ Annual Technical
Conference and Exhibition of the Society of Petroleum Engineers 1992; pp. 467-76.

[59] Wilhelms A, Larter SR, Head I, Farrimond P, Di Primio R, Zwach C. Biodegradation of oil in uplifted basins prevented by deep-burial sterilization. Nature 2001; 411: 1034-7.

[60] Head IM, Jones DM, Larter SR. Biological activity in the deep subsurface and the origin of heavy oil. Nature 2003; 426: 344-52.

[61] Meredith W, Kelland SJ, Jones DM. Influence of biodegradation on crude oil acidity and carboxylic acid composition. Org. Geochem 2000; 31: 1059-73.

[62] Sassen R. Biodegradation of crude oil and mineral deposition in a shallow Gulf Coast salt dome. Org. Geochem 1980; 2: 153-166.

[63] Hoşgörmez H. Origin and secondary alteration of coalbed and adjacent rock gases in the Zonguldak basin, western Black Sea Turkey. Geochem J 2007; 41: 201-7.

[64] Katz BJ, Almon WR, Atallah C, Schoell M, Tang Y. Gas resource quantification - a supplyside approach. Proceedings of International Conference on Gas Habitats of SE Asia and Australasia. Indonesia Petroleum Association 1999; pp.1-6.

[65] Katz B, Williams K. Biogenic gas potential offshore Guajira peninsula, Colombia. In: Bartolini C, Buffler RT, Blickwede JF, Eds, The Circum-Gulf of Mexico and the Caribbean: Hydrocarbon Habitats, Basin Formation, and Plate Tectonics AAPG Memoir 2003; 79: 961-8.

[66] James AT, Burns BJ. Microbial alteration of subsurface natural gas accumulations. AAPG Bull 1984; 68: 957-60.

[67] Larter SR, Head IM, Huang $\mathrm{H}$, et al. Biodegradation, gas destruction and methane generation in deep subsurface petroleum reservoirs: An overview. In: Doré, AG, Vinus BA, Eds. Petroleum Geology: North-West Europe and Global Perspectives Proceedings of the $6^{\text {th }}$ Petroleum Geology Conference, Geological Society (London) 2005; pp.633-9.

[68] Coleman DD, Risatti JB, Schoell M. Fractionation of carbon and hydrogen isotopes by methane-oxidizing bacteria. Geochim Cosmochim Ac 1981; 45: 1033-7.

[69] Schoell M. Genetic characterization of natural gases. AAPG Bull 1983; 67: 2225-38. 